\title{
THE HYPERSENSITIVITY REACTIONS TO PARA-AMINOSALICYLIC ACID (P.A.S.)
}

BY

\author{
STUART CARNE \\ General Practitioner, London
}

(RECEIVED FOR PUBLICATION APRIL 15,1957 )

Para-aminosalicylic acid (P.A.S.) was first used in 1946 for the treatment of tuberculosis by I ehmann (1946). With the exception of nausea and vomiting, which Lehmann himself described, it was at that time thought that the drug was free from sideeffects. However, with its increasing use, reports of other toxic reactions began to appear (Nagley and Logg, 1949: Hemming and Stewart, 1949) and there now exists an extensive literature on the subject.

These reactions fall into three groups (Dixon, 1954). First is a natural intolerance to the drug which as many as $58 \%$ of patients (Medical Research Council, 1950) experience, whose manifestations (nausea, vomiting and sometimes diarrhoea) appear very soon after starting the treatment.

Secondly, pharmacological side-effects have been described. These consist of hypoprothrombinaemia (Swanson, 1949), hypokalaemia (Cayley, 1950), hypothyroidism (Komrower, 1951) and hyperthyroidism (Tandhanand and Buri, 1956). The alterations in thyroid metabolism are usually associated with the occurrence of a goitre.

Thirdly, there are the hypersensitivity reactions, and these are usually the most serious. Table 1 lists these reactions.

Kniest (1952) has reported an anaphylactic reaction immediately after restarting treatment in two cases that had already shown some allergy to P.A.S., but this should be regarded as an exaggerated version of the normal hypersensitivity reaction.

The present case is reported because it shows so many of the hypersensitivity reactions to P.A.S., and helps to shed some further light on them. In addition, ascites and pleural effusion have not previously been reported as complications of P.A.S. therapy. Furthermore it is the first report of P.A.S. sensitivity following the administration of calcium B-P.A.S.
TABLE 1

THE HYPERSENSITIVITY REACTIONS TO P.A.S.

\begin{tabular}{|c|c|}
\hline $\begin{array}{l}\text { Fever } \\
\text { Skin rashes } \\
\text { Exfoliative dermatitis } \\
\text { Pruritus } \\
\text { Stomatitis } \\
\text { Headache } \\
\text { Lachrimation and conjunctivitis } \\
\text { Blood dyscrasias } \\
\qquad \text { (a) Eosinophilia } \\
\quad \text { (b) Glandular fever cells } \\
\quad \text { (c) Agranulocytosis } \\
\text { Vasomotor rhinitis } \\
\text { Lymphadenopathy } \\
\text { Hepatitis and hepatomegaly } \\
\text { Albuminuria and haematuria } \\
\text { Transient anuria } \\
\text { Anaphylactic shock } \\
\text { Angioneurotic oedema } \\
\text { Laryngeal stridor } \\
\text { Intractable cough } \\
\text { Asthma } \\
\text { Löffler's syndrome } \\
\text { Pleural effusion } \\
\text { Ascites }\end{array}$ & $\begin{array}{l}\text { Cuthbert (1950) } \\
\text { Horne (1949) } \\
\text { Cuthbert (1950) } \\
\text { Steel (1952) } \\
\text { Jeffery et al. (1952) } \\
\text { Hemming and Stewart (1949) } \\
\text { Warring and Howlett (1952) } \\
\text { Dixon (1954) } \\
\text { Cannemeyer et al. (1955) } \\
\text { Muri (1952) } \\
\text { 'Any Questions' (1953) } \\
\text { Cuthbert (1950) } \\
\text { Dixon (1954) } \\
\text { Nagley and Logg (1949) } \\
\text { Cuthbert (1950) } \\
\text { Kniest (1952) } \\
\text { Cuthbert (1950) } \\
\text { Warring and Howlett (1952) } \\
\text { Hemming and Stewart (1949) } \\
\text { Gerrits (1951) } \\
\text { Warring and Howlett (1952) } \\
\text { Present case }\end{array}$ \\
\hline
\end{tabular}

Calcium 4-Benzamidosalicylate (Calcium B-P.A.S. 'Therapas')

In an attempt to overcome the high degree of intolerance found when P.A.S. is administered as the normal sodium or calcium salt (in solution, in cachets or in granules), Bavin and James (1953) described this new substance which is insoluble and, perhaps for that reason, tasteless. It is broken down in the body to liberate P.A.S. and benzoic acid. Preliminary reports suggest that calcium B-P.A.S. is therapeutically as effective as the normal salts of P.A.S., and produces intestinal disturbances in a far smaller proportion of cases.

\section{Case Report}

The patient, a girl of 7 years, developed primary tuberculosis and was treated with I.N.H. and calcium B-P.A.S. There was nothing relevant in either her previous medical history or in her family history. Her 
elder brother (the only sibling) and both her parents were well and showed no evidence of active tuberculous infection: the contact was never found.

For convenience all dates have been related to the day she first received P.A.S. ('P' day, April 24). Fig. 1 illustrates the progress of the case.

31.3.56 The patient was seen with a rash on her shins (P-24) which resembled erythema nodosum.

2.4.56 Tuberculin jelly test positive, control negative.

(P-22)

4.4.56

$(\mathbf{P}-20)$

Radiological report (1).

5.4.56 Erythema nodosum settling slowly. A fairly

(P-19) constant evening pyrexia of $99^{\circ} \mathrm{F}$. noted.

20.4.56 Radiological report (2)

(P-4) Pathological report (2)

24.4.56 In view of the increasing radiological changes, (P day) antituberculosis therapy was started, using I.N.H. and 'calcium B-P.A.S.'.

20.4.56 A rubella-like eruption appeared during the $(\mathrm{P}+5)$ afternoon but lasted only two hours. Its significance was not appreciated.

12.5.56 The eruption recurred, and with it the tempera-

$(\mathrm{P}+18)$ ture rose to $101^{\circ} \mathrm{F}$. The cervical nodes, especially those in the posterior triangles, were enlarged.

14.5.56 For the first time nausea was experienced on $(\mathbf{P}+20)$ taking the B-P.A.S. The dose was reduced with no improvement.

17.5.56 The child's condition was much worse, and
$(P+23)$ she looked ill. An irritating morbilliform rash had replaced the rubella-like one and covered the whole body. The conjunctivae were suffused and her eyes were watering. Several small ulcers were present on the buccal mucosa and inside the mouth. The adenitis had increased considerably; not only were all the nodes in the neck enlarged, but also those in the axillae and groin, though the spleen could not be felt (nor could it at any other time). All antituberculosis therapy was stopped on this day.

18.5.56 The eyelids and face were swollen and the $(\mathrm{P}+24)$ ankles slightly oedematous. She was complaining of quite severe abdominal pain and on examination the liver edge was palpable and tender. The urine showed the presence of bile salts and pigments, and there was albumin ++ (bed-side analysis).

22.5.56

Liver edge palpable three fingerbreadths below the costal margin. Temperature $101-104^{\circ} \mathrm{F}$. Pathological report (3)

23.5.56

$(\mathrm{P}+29)$

26.5.56

$(\mathrm{P}+32)$

The temperature returned to normal, but the liver was now palpable five fingerbreadths and jaundice could be detected, though it was not at any time very marked.

28.5.56 Subjectively the child felt much better but on $(P+34)$ examination signs were detected in the chest for the first time. The percussion note was

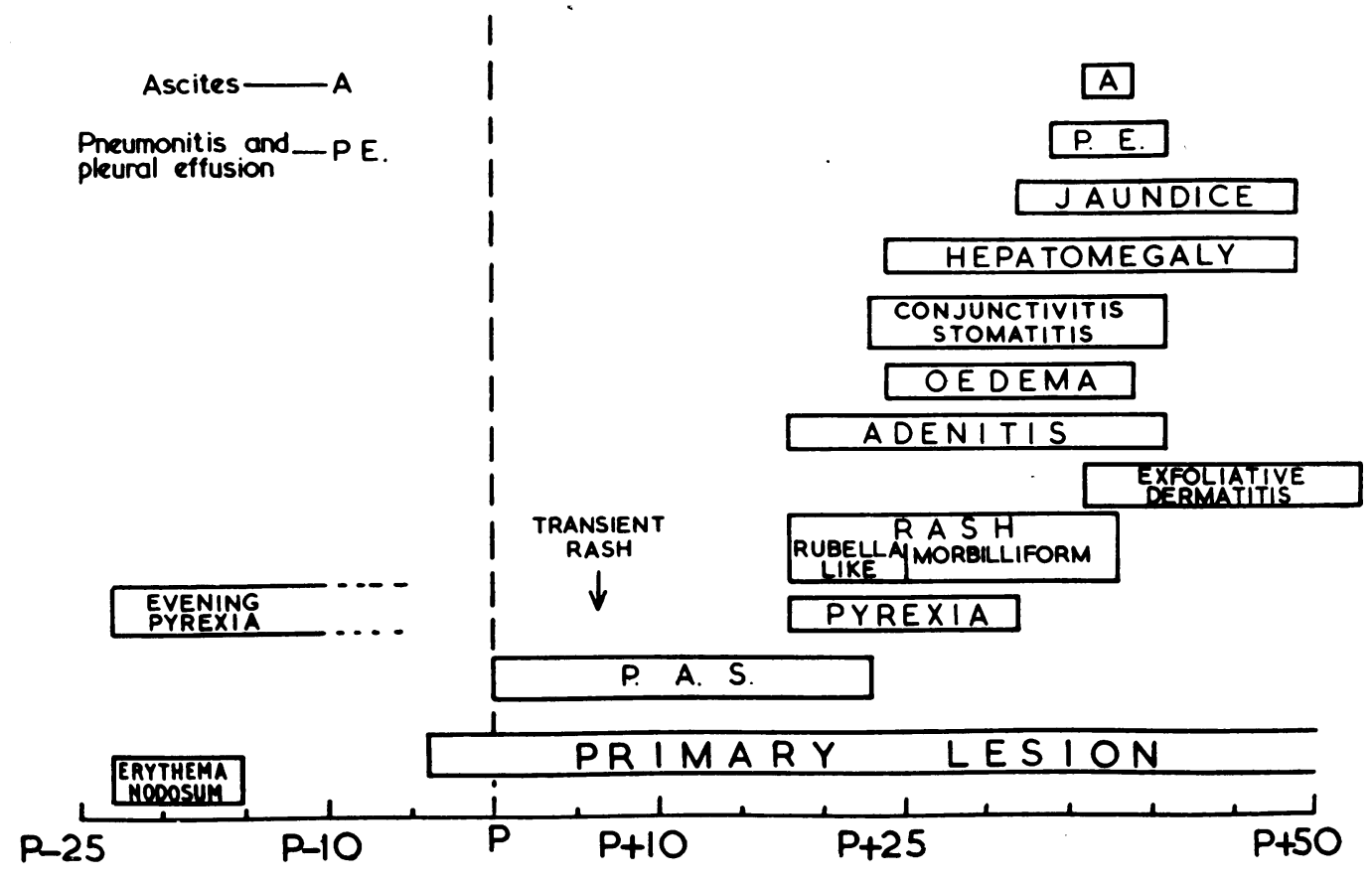

Fig. 1. 


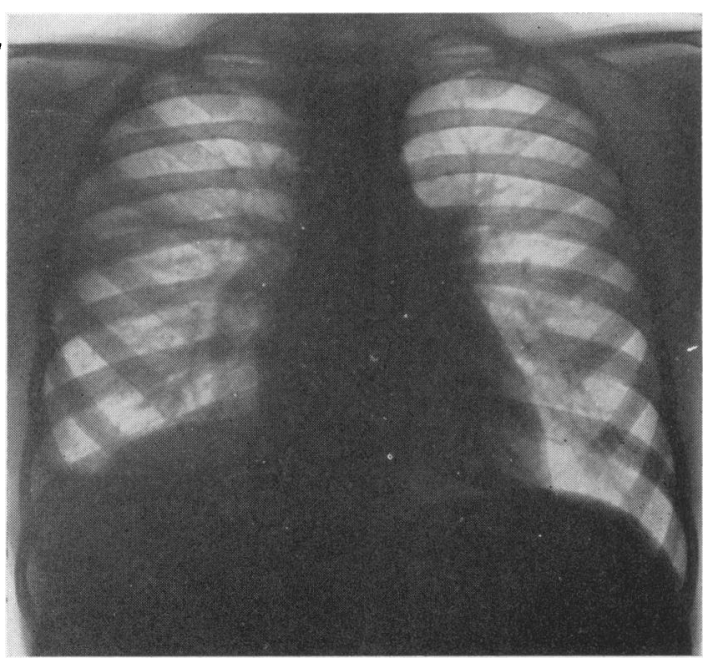

FIG. 2.

dull in the right axilla and air entry was diminished over the right lower lobe.

29.5.56 Radiological report (3)

$(\mathrm{P}+35) \quad$ Pathological report (4)

30.5.56 Ascites was found. The skin was beginning

$(\mathrm{P}+36)$ to peel over both thumbs and thenar eminences as the rash was starting to fade.

2.6.56 General condition much improved. Liver

$(P+39)$ edge decreased to two fingerbreadths. Ascites was now no longer detectable. The oedema had subsided. Pulmonary signs were unaltered. The exfoliation was spreading all over the body.

4.6.56 The chest was clinically clear. The oral and

$(P+41)$ conjuctival ulcers had settled. The adenitis was subsiding.

5.6.56 Radiological report (4)

(P+42) Pathological report (5)

12.6.56 All the signs had disappeared except for the

$(P+49)$ remains of the exfoliative process on the legs.

29.6.56 Child clinically very well. Appetite good.

$(P+66) \quad$ Up half day.

Radiological report (5)

Pathological report (6)

14.8.56 Gaining weight. Full activity.

$(\mathrm{P}+112) \quad$ Radiological report (6)

Pathological report (7)

11.10.56 Radiological report (7)

$(P+140)$ Pathological report (8)

1.10.56 Permitted to return to school.

$(\mathrm{P}+161)$

10.9.57 The child is clinically very well. The primary tuberculosis complex is no longer visible radiologically.

\section{Radiological Reports}

(1) 4.4.56 Lung fields clear. Left hilum a little suspicious.

(2) 20.4.56 The left hilar glands are enlarged and

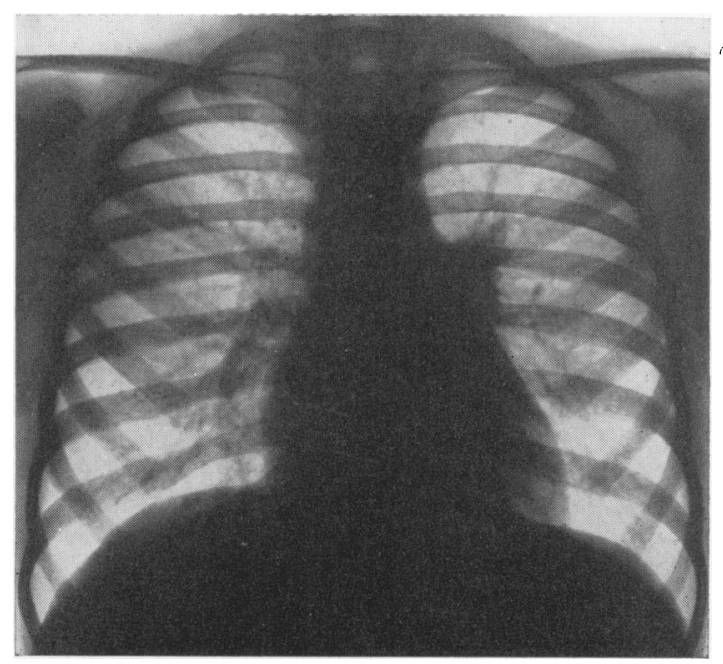

FIG. 3.

there is some consolidation in the apical segment of the lower lobe or in the posterior segment of the upper lobe. The radiological appearances are consistent with the presence of a primary tuberculous complex.

(3) 29.5.56 There is now a small effusion at the right base and some fluid is also present in the intralobar fissure. There may be a little atelectasis above it (Fig. 2).

(4) 5.6.56 The right lung field is now clear and there is no evidence of fluid. The left hilar mass is unchanged (Fig. 3).

(5) 29.6.56 The position of the left hilum has not altered materially.

(6) 14.8.56 Comparison with the previous films shows little change. The left hilar glands are still enlarged.

(7) 11.9.56 The enlarged glands at the left hilum have not altered materially in size in the last month.

\section{Pathological Reports}

(1) $4.4 .56 \mathrm{Hb} 11 \cdot 2$ g. $\%$. W.B.C. 7,600 per c.mm. (5,800 polymorphs, 1,700 lymphocytes, 100 monocytes). E.S.R. $42 \mathrm{~mm}$. $/ \mathrm{hr}$.

(2) 20.4 .56 Hb $12 \cdot 8$ g. $\%$. W.B.C. 13,000 per c.mm. (8,400 polymorphs, 3,900 lymphocytes, 700 monocytes). E.S.R. $41 \mathrm{~mm}$. $/ \mathrm{hr}$.

(3) $23.5 .56 \mathrm{Hb} 12 \cdot 3$ g. \% $\quad$ W.B.C. 9,000 per c.mm. (3,500 neutrophils, 500 eosinophils, 5,000 lymphocytes). A few of the mononuclear cells were atypical and resembled those seen in glandular fever.

(4) 29.5.56 Urine: amber yellow. S.G. 1·016, pH. $7 \cdot 0$, albumin nil, bile salts nil, glucose nil, bile pigments ++ , urobilinogen 1.5 units $\%$, 6 leucocytes and less than 1 R.B.C. per c.mm.

(5) $5.6 .56 \mathrm{Hb} 12 \cdot 7$ g. \%. W.B.C. 13,000 per c.mm. (7,600 polymorphs, 6,300 lymphocytes, 600 monocytes). E.S.R. $24 \mathrm{~mm}$./hr. Urine: bile salts + , bile pigments ++ , urobilinogen $1 \cdot 1$ units $\%$. A few of the monocytes were atypical. Paul-Bunnell test was positive to $1: 16$ only, i.e., negative. 
(6) $29.6 .56 \mathrm{Hb} 13.0$ g. \%. W.B.C., no abnormal cells seen. E.S.R. $31 \mathrm{~mm} . / \mathrm{hr}$.

(7) $14.8 .56 \mathrm{Hb} 13.4$ g. $\%$. E.S.R. $15 \mathrm{~mm} . / \mathrm{hr}$. Stool was solid dark brown, no blood or mucus, no ova or cysts.

(8) 11.9 .16 Hb. 13.0 g. \%. E.S.R. 5 mm./hr.

\section{Discussion}

Jaundice and hepatomegaly are well-known complications of P.A.S. therapy and Dixon (1954) has reviewed the literature. In almost all the cases reported, other toxic symptoms were present; of those cases referred to by Dixon, lymphadenopathy, exfoliative dermatitis, and oedema of the face were common accompaniments as well as eosinophilia which was more often than not part of a generalized leucocytosis. Dixon, however, makes no mention of the presence or absence of 'glandular fever cells'.

A reaction to P.A.S. resembling infectious mononucleosis (glandular fever) was first described by Sjoukes (1952). Warring and Howlett (1952) included this complication in their list and referred to a Veterans Administration report on the subject. Several cases have since been reported by Lichtenstein and Cannemeyer (1953) and these authors (Cannemeyer, Thompson and Lichtenstein, 1955, have elsewhere discussed the haematological changes at greater length. All their eight cases were accompanied by a skin rash which was usually erythematous and macular. Lymphadenopathy was found in half the cases. Two had hepatomegaly (one of which was jaundiced) and blood changes of hepatitis (raised alkaline phosphatase, thymol turbidity, and bilirubin, as well as a positive cephalin flocculation test) were found in most of the cases investigated. Also found in most of their cases was a lymphocytosis-relative or absolute-while the PaulBunnell test was always repeatedly negative.

It appears that there is a considerable connexion between the two reactions in that symptoms of both the syndromes are usually found whenever they occur as complications of P.A.S. therapy. The present case is further evidence.

A transitory pneumonitis associated with an eosinophilia (Löffler's syndrome) as one of the hypersensitivity reactions to P.A.S. was first reported by Warring and Howlett (1952). Löffler's syndrome when it is due to other causes has been accompanied by a pleural effusion (Crofton, Livingstone, Oswald and Roberts, 1952) as it was in the present case. It is unlikely that either the pneumonitis or the effusion was tuberculous for both cleared completely in a week. Neither ova nor cysts were found in the stools.

The ascites was also probably due to the 'therapas', for the degree of hepatitis was insufficient to account for it, and there was no splenomegaly.
Stomatitis and conjunctival suffusion together with a puffy face and generalized oedema are typical of a drug fever, and albuminuria is often found in the same condition. The rash, too, which resembled erythema multiforme, can occur with a drug fever, and, as mentioned above, it also often accompanies the hepatitis and 'glandular fever reaction' following P.A.S.

Allergic reactions to P.A.S. therapy are not common in children (Todd, 1953) though they do suffer the same natural intolerance to the drug. Hepatitis does not appear to have been reported previously in a child though Oppe (personal communication) had a case which ended fatally. Both of Kniest's (1952) cases of anaphylactic reaction were in children, the older of whom (aged 12) died from a concomitant flare-up of a tuberculous infection.

\section{Summary}

A case is reported of a child treated with P.A.S. who developed hypersensitivity reactions. These reactions included drug fever, lymphadenopathy with 'glandular fever cells' in the blood, hepatitis with jaundice and dermatitis with exfoliation. In addition the child developed Löffler's syndrome with a pleural effusion and had ascites.

I wish to thank Drs. J. Fielding and P. L. Masters for the pathological reports and Drs. T. R. Riley and J. J. Stevenson for the radiological reports.

Considerable advice was received from the St. Mary's Hospital Home Care Department, though, because the patient lived outside the area they cover, she did not come into their scheme. I would like to thank Dr. Lightwood and his team for all their assistance, and in particular I wish to thank Dr. Lightwood for his help in the preparation of this paper. I would also like to thank Dr. B. Kustow, whose patient the child is, for his permission to look after the child, and for his encouragement.

\section{REFERENCES}

'Any Questions' (1953). Brit. med. J., 2, 296

Bavin, E. M. and James, B. (1953). J. Pharm. Pharmacol., 5, 849. Cannemeyer, W., Thompson, J. R. and Lichtenstein, M. R. (1955) Blood, 10, 62

Cayley, F. E. de W. (1950). Lancet, 1, 447.

Crofton, J. W., Livingstone, J. L., Oswald, N. C. and Roberts, A. T. M.'(1952). Thorax, 7, 1 .

Cuthbert, J. (1950). Lancet, 2, 209.

Dixon, W. M. (1954). Brit. J. Tuberc., 48, 102

Gerrits, J. C. (1951). Geneesk Gids, 29, 169.

Hemming, M. and Stewart, C. J. (1949). Lancet, 2, 174

Horne, N. W. (1949), Ibid., 2, 349.

Jeffery, Borrie, P. and MacDonald, N. (1952). Brit. med. J., 2, 647.

Kniest, W. (1952), Dtsch. med. Wschr., 77, 676.

Kniest, W. (1952). Dtsch. med. Wschr., 77, 676.

Lommawer, G. M. (1946). Lancet, 1, 15.

Lichtenstein, M. R. and Cannemeyer, W. (1953). J. Amer. med. Ass., 152, 606.

Medical Research Council (1950). Ibid., 2, 1073.

Muri, J. (1952). Nord. Med., 47, 155.

Nagley, M. M. and Logg, M. H. (1949). Lancet, 1, 913.

Nagley, M. M. and Logg, M. H. (1949)

Sjoukes, P. (1952). Ned. T. Geneesk., 96, 2001.

Sjoukes, P. (1952). Ned. T. Geneesk.,

Swanson, J. N. (1949). Lancet, 2, 175. Cited on p. 349 by O'Connor, J. A.

Tandhanand, S. and Buri, R. (1956). Brit. med. J., 2, 281

Todd, R. McL. (1953). Brit. med. J., 1, 1247.

Warring, F. C. and Howlett, K. S. (1952). Amer. Rev. Tuberc., 65, 235 . 